\title{
MODEL PENGAMBILAN KEPUTUSAN BERWISATA
}

\author{
Hari Rachmadi, S.E., M.M. \\ NIDN : 0505076501 \\ e-mail :harri.rachmadi@yahoo.com \\ Dosen Sekolah Tinggi Pariwisata AMPTA Yogyakarta
}

\begin{abstract}
Travelling decision model reflect the Characteristics and type of travel .If diffierenciates and comparcs the tendencies of decison making behaviour in different situational .

The Travelling decisaion is established by the different motives of each individuals and group. Where the situational factor affect the bahviour of decison making.Most of the decison making process require the involvement of bahviour in using the information like in the conteporaray decision making.one of the example is the decision to traveling .

The logical decision making is the decison made through clear steps that reflects the different characteristcs of behaviour in specifis desicion situations whisc the values are velaved and chesen tourist destination are suitable and desirable
\end{abstract}

\section{PENDAHULUAN}

Sampai saat ini, kajian terhadap proses pengambilan keputusan konsumen selalu menjadi topik dalam diskuis, karena, tidak ada teori tunggal yang muncul sebagai disiplin ilmu untuk menggambarkan, menjelaskan, atau memprediksi keputusan konsumen, dan tampaknya tidak mungkin bahwa proses keputusan individu cocok dengan teori keputusan tunggal. ( Sirakaya, E. and Woodside, A.G. 2005) Keputusan tetap merupakan fenomena yang sangat kompleks dan menarik terhadap tujuan wisata yang ditawarkan, variasi dalam jenis liburan, dan peningkatan jumlah pengunjung, keputusan kapan waktu berwisata dan pendapatan bagi pelaku bisnis wisata. Memahami proses pengambilan keputusan sangat penting untuk keberhasilan destinasi wisata dan bisnis pariwisata. Fokus yang signifikan terhadap proses keputusan mampu menarik banyak perhatian para ilmuan, akademisi dan praktisi marketing khususnya bidang perilaku konsumen.

Kenyamanan proses wisata, kompleksitas dan peluang penyimpangan struktural menyarankan arah keputusan tepat. Banyak keputusan dibuat setelah pengunjung tiba, mengidentifikasi serangkaian sub-keputusan baik sebelum dan selama perjalanan. Penggunaan rantai nilai, memberikan bukti bahwa persepsi perjalanan didasarkan pada pengalaman terkait. Unsur-unsur dalam rantai nilai mempengaruhi pengalaman perjalanan.

$$
\text { Proses dinamis pengambilan }
$$

keputusan berwisata tidak terstruktur dan penuh kontinjensi- (Sharma, A. and Christie, I.T. 2010) Untuk mempermudah pengambilan keputusan, wisatawan membagi keputusan ke dalam keputusan yang lebih kecil dan lebih akrab. Misalnya, merencanakan perjalanan dipecah menjadi sub-rutin seperti pilihan destinasi, transportasi, penginapan, kegiatan utama,aktifitas di destinasi dan kegiatan 
kontingensi dimana keputusan jarang ditemui akan mempengaruhi keputusan perjalanan.

Model pengambilan keputusan yang terstruktur menjelaskan proses organisasi mempekerjakan ketika menghadapi keputusan terstruktur. Model ini mengurangi keputusan dalam fase identifikasi, pengembangan, dan seleksi. Setelah fase identifikasi, satu atau lebih akrab dengan rutinitas akan memandu pembuatan keputusan melalui proses. Rutinitas dan keakraban diharapkan dapat mengurangi kompleksitas keputusan ini. Model ini bisa lebih kompleks karena bisnis melibatkan kelompok stakeholder lainnya. Pengambilan keputusan berwisata menjadi lebih komplek ketika wisatawan mengahdapi dua atau tiga destinasi (daerah tujuan wisata) yang harus dikunjungi dalam waktu yang bersamaan dalam jumlah waktu dan sumber dana yang terbatas.

\section{PERAN PENTING PERILAKU WISATAWAN}

\section{Adaptasi Model}

Seperti dalam produk barang, perilaku perjalanan (travel) juga menjadi fokus penelitian pariwisata sebagai upaya untuk mengungkap faktor-faktor penentu perilaku wisata terutama untuk kepentingan bisnis. Para pelaku bisnis perjalanan menyadari bahwa perlunya memahami perilaku perjalanan, terutama proses pengambilan keputusan perjalanan dalam lingkungan bisnis perjalanan wisata yang saat ini semakin kompetitif. Memahami kebutuhan wisatawan "mengapa" dan "bagaimana" perilaku perjalanan itu menjadi dasar bagi praktek pemasaran pariwisata yang efektif.

Model perilaku wisatawan dimodifikasi atau disesuaikan dengan perilaku perjalanan wisata. Penataan proses keputusan perjalanan individu, keluarga atau komunitas dan aktivitas dalam berwisata berlangsung dalam empat tahap: merupakan dasar dalam membuat pilihan daerah tujuan wisata (DTW), tahap ini menggabungkan variabel demografi berdasarkan ingatan sadar dan tidak sadar, dan pengaruh eksternal untuk membuat kriteria dalam menentukan pilihan destinasi wisata.

evaluasi alternatif pilihan destinasi wisata berdasarkan driver kegiatan utama yang dikaitkan dengan kendala anggaran. Jika kriteria kunci yang dipertimbangkan sempurna dan buku-buku petunjuk perjalanan, web DTW serta medsos tersedia, perjalanan akan dilanjutkan. Jika tidak sempurna, wisatawan akan kembali ke tahap pertama. Jika salah satu titik kritis tidak terpenuhi, perjalanan dibatalkan.(Martin,

D. and Woodside, A.G. 2011) terjadi selama liburan, tahap ini terjadi setelah tahap pertama dan kedua dapat dilewati. Tahap ini sangat dinamis karena rangsangan tambahan baru bisa muncul menciptakan alternatif baru dan menghilangkan

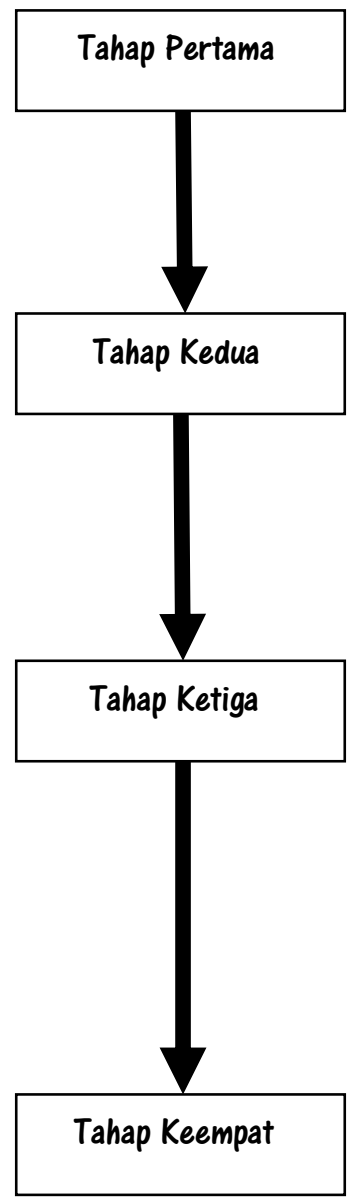
kegiatan yang direncanakan. Jika sesuatu yang hilang dari tahapan keputusan, perubahan rencana di sebuah daerah tujuan wisata, dimana kejutan positif atau negatif 
akan mempengaruhi evaluasi berkelanjutan perjalanan wisata meraka.

proses refleksi diri, evaluasi perjalanan wisata ini mempengaruhi proses perencanaan perjalanan berikutnya. Kenangan yang dinamis dan interpretasi individu bervariasi dari waktu ke waktu serta situasi. Kenangan berfungsi sebagai pengaruh eksternal menjadi kelompok referensi dalam membingkai perjalanan wisata berikutnya. Tahap ini penting karena kesetiaan terhadap destinasi dan pengaruh objektif tentang referensi perilaku kelompok adalah kunci untuk pertumbuhan destinasi wisata.(Drew, Martin and Woodside, Arch G. 2012).

Para akademisi marketing telah mencapai konsensus dalam mengenali proses keputusan wisatawan 'sebagai pendekatan yang berguna dalam memahami dan menjelaskan perilaku perjalanan wisata dan sebagai alat yang efektif dalam membuat perencanaan pemasaran pariwisata. (Katsoni, Vicky and Venetsanopoulou.Maria. 2013) Proses pengambilan keputusan wisata, meskipun beberapa yang secara seketika mendapatkan keputusan pembelian yang menguntungkan, terutama keputusan pembelian ulang sebagai basis dalam membangun loyalitas, pemasar termasuk travel agent, tour leader,tour guide harus "menemani" wisatawan melalui proses pembelian, dan menyesuaikan upaya pemasaran dalam mengembangkan (1) rangsangan eksternal seperti publikasi perdagangan; (2) kebutuhan dan keinginan ditentukan oleh kepribadian, faktor sosial-ekonomi, sikap, dan nilai-nilai perjalanan wisata; (3) variabel eksternal seperti kepercayaan terhadap agen perjalanan, citra destinasi wisata, pengalaman sebelumnya, biaya dan kendala waktu; dan (4) destinasi atau karakteristik layanan yang memiliki pengaruh besar terhadap proses pengambilan keputusan dan hasilnya.( Minciu, Rodica and Moisă, Claudia, Olimpia. 2009 ) Model ini bertujuan untuk menunjukkan variabel yang relevan dan keterkaitan mereka dalam proses pengambilan wisata, dimana tindakan pemasaran dapat:

a. Digunakan untuk mempengaruhi proses pengambilan keputusan dan faktor-faktor khusus yang memiliki pengaruh terhadap keputusan perjalanan

b. Digunakan untuk menentukan kriteria yang mentargetkan pasar minat khusus atau destinasi wisata dapat diidentifikasi secara deskriptif dan tidak dapat diukur

c. Berfungsi sebagai dasar memprediksi permintaan terhadap destinasi wisata atau layanan tertentu.

Pengambilan keputusan wisatawan individual dipengaruh oleh faktor psikologis dan sosial. Keputusan perjalanan berkaitan dengan meninggalkan rumah, ke destinasi mana, apa yang harus dilakukan, bagaimana menuju ke sana, berapa banyak uang yang diperlukan, berapa lama tinggal, tempat menginapnya dimana, tempat makan, dan dengan siapa bepergian umumnya dibuat dengan memanfaatkan beberapa pendekatan yang berbeda. Keputusan ini bisa terjadi secara rutin, atau wisatawan membuat keputusan dengan cepat tanpa memerlukan waktu yang panjang, mencari informasi dan mengevaluasi alternatif yang tersedia untuk membuat keputusan yang lebih luas, yang pada umumnya dimulai dari (1) adanya kebutuhan atau keinginan berwisata, (2) pengumpulan informasi dan evaluasi, (3) keputusan wisata, (4) persiapan perjalanan dan pengalaman berwisata, dan (5) evaluasi 
kepuasan berwisata yang dipengaruhi oleh (1) profil wisatawan, (2) kesadaran perjalanan, (3) fitur perjalanan, (4) sumber daya dan karakteristik destinasi.(Abraham Pizam and Yoel Mansfeld. 2009 ).

Kajian empiris dalam pengambilan keputusan mengikuti dua perspektif yang berbeda. Perspektif pertama efektifitas pengambilan keputusan yang terkait dengan sikap, keyakinan, keterlibatan, persepsi risiko, sifat, dan kepribadian. Perspektif kedua, memprediksi pengambilan keputusan, dan pilihan destinasi untuk maksimalisasi utilitas.(Anshul Garg. 2015. Travel Risks vs Tourist Decision Making)

\section{Profil Pengunjung}

Jumlah pengunjung dapat
menunjukkan pertumbuhan pasar pariwisata secara signifikan. Sebagai contoh misalnya saja pariwisata DIY pada tahun 2014 jumlah pengunjung ke daya tarik wisata yang ada di DIY 3.091.967 orang, dan tahun 2015 meningkat menjadi 3.813 .720 (pertambahan 721.753) orang, naik sebanyal 23\%. Demikian juga wisatawan mancanegara di tahun 2014 mencapai 254.213 orang dan pada tahun 2015 jumlah kunjungan wisatawan mencapai 308.485 orang, naik sebesar 21\%.( Aris Riyanta, 2016. Laporan Kinerja Dinas Pariwisata DIY) Pertumbuhan ini membantu mempopulerkan kota Yogyakarta dan membantu mengimbangi masalah musiman yang dihadapi oleh pelaku wisata di Kota Yogyakarta. Kontribusi nilai ekonomi pasar pariwisata ini semakin diakui oleh semua pihak.

Definisi travel yang paling banyak digunakan adalah, perjalanan liburan pendek ke satu kota atau destinasi wisata lainnya, (Trew, J. and Cockerell, N. 2002. The market for city breaks) mereka menciptakan atau mengikuti lingkungan sosial dan budaya baru. Pertumbuhan perjalanan dapat dikaitkan dengan sejumlah faktor, termasuk ekspansi maskapai penerbangan dengan biaya rendah ( Low Cost Carriers ) dan kecenderungan liburan yang pendek mendorong orang sering melakukan perjalanan. Faktor lain yang sama pentingnya adalah persepsi kota yang berubah sebagai destinasi sebagai tempat transit untuk istirahat atau tujuan yang diinginkan oleh wisatawan itu sendiri.

Dalam kasus city tour merupakan aktivitas liburan yang mengunjungi satu kota, sementara non city tour terdiri dari orang-orang yang melakukan perjalanan yang yang melibatkan destinasi wisata lain yang lebih beragam. Profil wisatawan dapat dideteksi dari geografis, demografis, psikografis, dan perilaku akan mempengaruhi jenis perjalanan dalam mewakili pilihan liburan terutama yang lebih mudah diakses oleh calon wisatawan. (Richter, L.K. 2003, 'International tourism and its global public health consequences). Profil dan perilaku pengunjung menunjukkan perbebedaan akses informasi dalam membuat pemesanan. Misalnya banyak wisatawan yang secara signifikan melakukan pesanan paket wisata dengan OTA (On line Travle Agent). Selain itu, perilaku wisatawan cenderung menampilkan pola pengambilan keputusan lebih bersifat impulsif (misal pesanan menit terakhir dan tiket murah) memiliki pengaruh cukup besar terhadap keputusan mereka untuk berwisata.

City tour menunjukkan preferensi liburan yang jelas dalam jangka waktu yang pendek, terutama untuk perjalanan berdurasi satu sampai tiga malam. Para pengunjung dapat memahami atraksi dalam beberapa hari. Karakteristik penting lainnya adalah pola kedatangan yang ditunjukkan oleh city traveler (Moore, Kevin. Smallman, Clive. Wilson, Jude and 
Simmons, David. 2012) yang sangat populer dimana orang datang dengan pasangan atau terkadang dengan anak-anak mereka atau musim liburan sekolah. Di Indonesia kecenderungan wisatawan domistik dan mancanegara untuk melakukan kegiatan pariwisata dalam jumlah yang signifikan pada musim yang berbebeda seperti berikut ini.

\section{Perilaku Pemesanan}

Perilaku pemesanan (booking

behavior) menunjukkan dimana orang melakukan pembelian paket perjalanan. dalam tiga kecenderungan: (Sava, Cipriana, 2013. The Evolution of Regional Accommodation Capacity Development Region) Pertama, kebanyakan anggaran wisata digunakan untuk transportasi (termasuk menyewa mobil) dan akomodasi. Pola perilaku pemesanan menit terakhir, menunjukkan mayoritas orang membeli paket wisata kurang dari satu bulan sebelum keberangkatan (perilaku impulsif), perilaku perjalanan ini, internet biasanya memainkan peran penting dalam pengambilan keputusan yang relatif cepat. Berbeda dengan liburan tahunan yang sering mengikuti pola pengambilan keputusan yang luas, dapat dipahami, diteliti dan memesan dalam hitungan hari atau bahkan jam.

Kedua, pelacakan informasi secara online dapat menampilkan secara signifikan selama proses pengambilan keputusan berwisata secara keseluruhan. Orang mengandalkan internet untuk mencari, mengevaluasi, dan pemesanan liburan mereka, kualitas tawaran liburan lewat internet/web harus lebih mudah diakses, jangan membuat calon wisatawan frustrasi saat mengakses informasi. Keberhasilan perjalanan adalah komposit, semua titik sentuh layanan termasuk proses pencarian informasi menjadi salah satu indikator penting kepuasan wisatawan secara keseluruhan.

Tabel 1. Kecenderungan Wisatawan Melakukan Perjalanan

\begin{tabular}{|l|l|l|l|}
\hline \multicolumn{2}{|l|}{ Wisatawan Domistik } & Wisatawan Mancanegara \\
\hline Kunjungan & Musim & Kunjungan & Musim \\
\hline Februari - Juni & Low & Februari - Juni & Low \\
\hline Juli - Agustus & High & Juli - September & High \\
\hline September - Januari & Medium & Oktober - Januari & Medium \\
\hline
\end{tabular}

Ketiga, dalam mengevaluasi keputusan berwisata bergerak dalam tahapan yang berbeda. Dalam banyak kasus tidak ada diferensiasi yang jelas antara unsur-unsur pencarian informasi, pilihan, dan pembelian. Pada sejumlah orang, tiga tahap tersebut dilakukan hampir bersamaan dan ketika memutuskan untuk menggunakan pemesanan secara online dan mencari penerbangan murah ke destinasi dapat dilakukan dengan sangat cepat.

\section{MODEL PENGAMBILAN KEPUTUSAN BERWISATA}

Para akademisi marketing menyajikan banyak model yang menunjukkan bahwa sebagian besar model pengambilan keputusan liburan disajikan baik dalam bentuk pilihan maupun bentuk proses 
kognitif.(Decrop, A. 2007. The formation of destination choice sets) Pilihan pendekatan, menekankan pada proses pilihan destinasi wisata, telah menerima perhatian khusus pendekatan yang lebih kompleks, dan dengan perpanjangan penggunaan praktisnya bagi pemasar destinasi wisata. (Jeng, J. and Fesenmaier, D.R. 2002)

Sebagian besar model pengambilan keputusan awal yang berkaitan dengan pembelian diadaptasi dari model grand perilaku konsumen, karena model ini pada awalnya dikembangkan untuk aplikasi produk nyata pada layanan pariwisata yang terbatas. Sebagian besar lainnya masih menganggap pembuat keputusan menjadi rasionalistis dan logis. Pada kenyataannya, keputusan sering dapat dipengaruhi oleh daya tarik emosional produk atau saran dari keluarga dan teman-teman.

Banyak model menganggap proses keputusan itu berurutan, mengikuti pola penyaluran energi pembuat keputusan melalui berbagai alternatif secara sistematis sampai pada pilihan akhir. Model mengasumsikan bahwa orang mengikuti urutan yang logis dan rasional. Namun, karena sifat subjektif dan adaptasi wisatawan adalah penting untuk mengenali, bahwa tidak ada satu jenispun yang lebih mungkin dalam proses membuat keputusan liburan yang sempurna.(Hyde, Kenneth F, and; Decrop, Alain. 2011) misalnya perilaku "pembelian impulsif - spontan pada menit terakhir" dan meningkatnya penggunaan Internet dan sistem multimedia yang dapat diakses oleh para wisatawan. Sebuah model merupakan "stereotipe umum", dimana proses pengambilan keputusan akan berbeda secara signifikan antara individu atau kelompok wisatawan.yang berbeda. (Swarbrooke, J. and Horner, S. 2007) Ini adalah titik awal yang valid, dan para akademisi marketing menyadari pentingnya jenis perjalanan dalam memahami perilaku pengunjung.

Jenis perjalanan sebagai elemen penting dalam proses pengambilan keputusan. Dalam beberapa situasi pemilihan destinasi wisata dapat menjadi faktor penting kedua dalam proses pengambilan keputusan. Untuk jenis liburan tertentu, oportunistik, atau pembelian menit terakhir, faktor-faktor seperti event, durasi, jarak, dan fleksibilitas mungkin memiliki pengaruh kuat pada perilaku pengambilan keputusan. Para akademisi marketing memperhitungkan jenis perjalanan, dan memeriksa proses pengambilan keputusan liburan dalam sebuah model.(Sung, H.H., Morrison, A.M., Hong, G.S. and O'Leary, J.T. 2001)

Gambar 1 menyajikan model tahapan dalam proses pengambilan keputusan dan dalam banyak literatur perilaku konsumen menunjukkan sejumlah karakteristik perilaku yang berbeda dalam pengambilan keputusan untuk melakukan perjalanan.

\section{A. VARIABEL STIMULUS}

Variabel stimulus merupakan influencer utama dalam keputusan berwisata: Pertama variabel internal mengacu pada aspek-aspek pribadi wisatawan seperti, motivasi, citra diri, kepribadian, gaya hidup, sikap, kepercayaan, tahap siklus hidup dan nilainilai (fungsional, sosial, kondisional, emosional, dan epistemic); kedua variabel eksternal meliputi, kendala, faktor penarik dari tujuan, bauran pemasaran, pengaruh keluarga dan referensi kelompok, budaya dan subkultur, dan kelas sosial; dan ketiga variabel situasional, yang berkaitan dengan sifat perjalanan yang signifikan dalam konteks wisata karena mengacu pada fitur 
seperti jenis daya tarik wisata, ukuran partai, jarak, waktu, dan durasi perjalanan yang secara langsung menjadi bsis pengelompokan perilaku kunjungan yang berbeda.

1. Motif Pendorong - Push motives

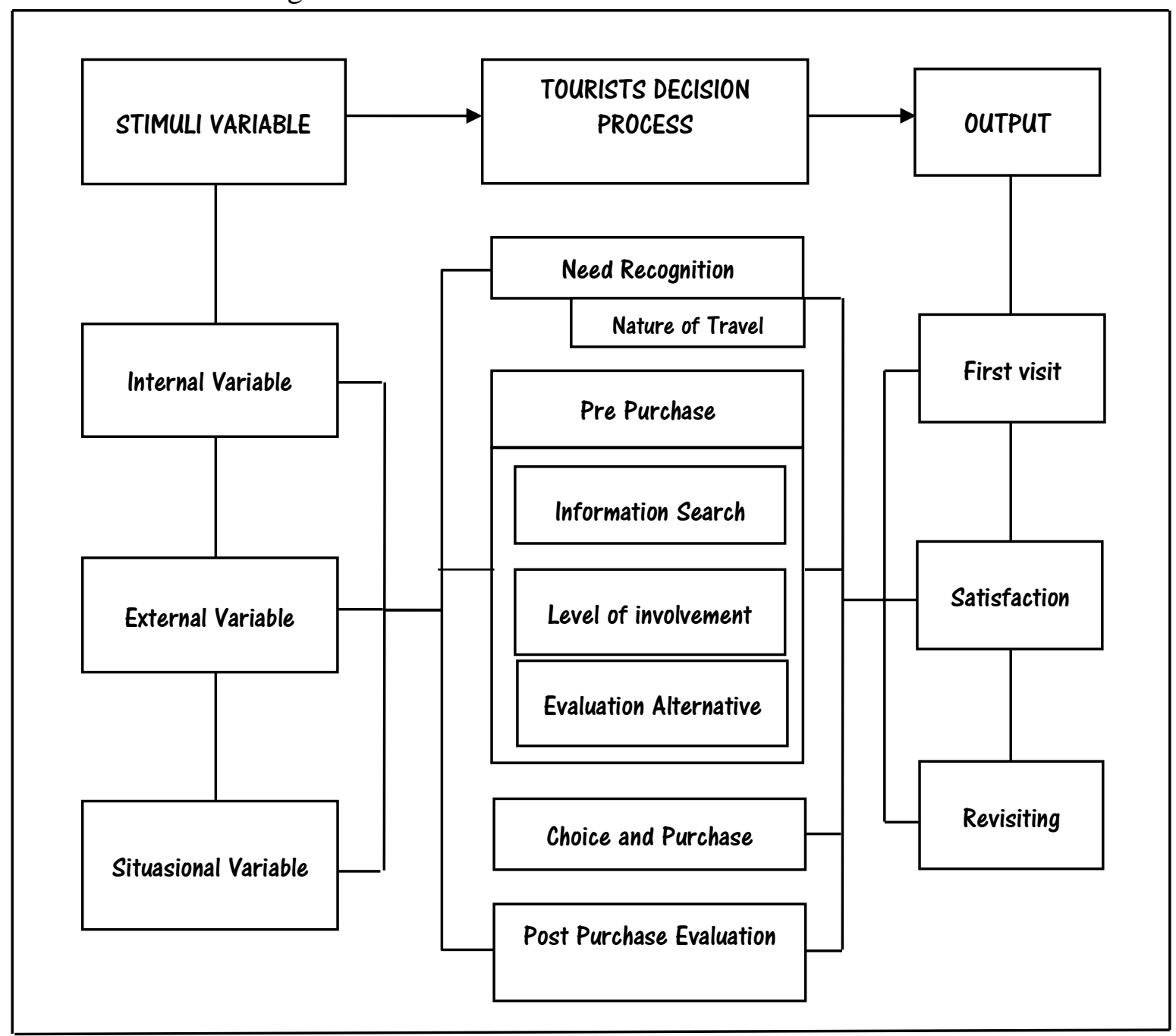

Gambar 1. Model Pengambilan Keputusan Wisatawan

Keinginan untuk melarikan/ melepaskan diri dari di lingkungan rumah muncul sebagai dorongan motif terkuat pertama bagi pengunjung wisata. Mengacu pada fenomena dorongan ini merupakan gagasan seseorang melakukan perjalanan untuk menjauh dari lingkungan semula. Orang yang melarikan/ melepaskan diri itu bervariasi, pada sebagian besar orang ingin melakukan perjalanan untuk menjauh dari situasi dan kondisi kehidupan sehari-hari yang membosankan. Ketika paket perjalanan yang disediakan oleh perusahaan dengan layanan pariwisata yang cepat, nyaman dan relatif murah ini menjadi kesempatan untuk melakukan perjalanan wisata - dalam konteks ini ada perbedaan yang signifikan antara motif travel dan motif liburan: Pertama; banyak orang yang menggunakan traveler sebagai jeda dari tekanan kehidupan sehari-hari yang membosankan: Kedua, pariwisata sebagai kebutuhan dan atau keinginan individu atau kelompok atau masyarakat untuk 
melakukan perjalanan bersama keluarga atau komitmen tahunan untuk melakukan hal-hal tertentu di destinasi (tempat tujuan wisata), misalnya merayakan ulang tahun, atau sekedar jalan-jalan, mengunjungi pub dan klub, menghadiri acara-acara, dan menyaksikan atraksi lainnya - mereka ini lebih menekankan pada releksasi atau bersenang-senang

Motif yang paling populer kedua untuk melakukan perjalanan adalah keinginan untuk memenuhi kebutuhan sosial. Ini adalah motif dorongan umum dalam banyak literatur motivasi. Motif sosial dibedakan menjadi dua kategori utama: peningkatan hubungan kekerabatan dan fasilitasi interaksi sosial. Keinginan untuk meningkatkan atau memperkaya hubungan keluarga, sedangkan yang kedua merupakan kebutuhan untuk "bertemu orang baru di lokasi wisata yang berbeda."kedua motif ini diklasifikasikan sebagai sosialisasi internal dalam komunitas, dan sosialisasi eksternal di luar komunitas.

Dalam perjalanan wisata, keinginan untuk meningkatkan hubungan dalam konteks mitra, pasangan atau orang dewasa lainnya, berbeda dengan liburan di mana peningkatan hubungan sebagian besar melibatkan unit keluarga yang lebih luas termasuk anak-anak. kesempatan untuk berkumpul bersama dan menghabiskan "waktu yang berkualitas" sebagai sebuah keluarga. Demikian pula, perbedaan antara jenis liburan dalam kaitannya dengan sosialisasi eksternal. Pariwisata menawarkan kesempatan untuk bertemu dan berinteraksi dengan penduduk setempat (hosting), bersosialisasi eksternal seperti itu jelas merupakan fitur penting dari sebuah liburan.
2. Faktor Penarik - Pull motives

Keakraban dan asosiasi dengan destinasi wisata menjadi daya tarik lokasional (pulled factor) bagi wisatawan. Produk pariwisata dievaluasi berdasarkan hasil pengalaman masa lalu, menyenangkan atau mengecewakan. Produk pariwisata dimaknai dari image, brand, dan popularitas.destinasi. Faktor penarik yang sangat penting dalam keputusan wisata berhubungan dengan atribut dari destinasi. Kekuatan faktor penarik ini berkaitan karakteristik wisatawan misalnya wisatawan psichocentric dimana image, branded, popularitas.destinasi, transportasi atau penerbangan murah, kemudahan akses, keamanan dan kenyamanan sangat berpengaruh dalam membuat keputusan untuk melakukan perjalanan wisata - dan keinginan yang kuat untuk bersantai saat liburan di destinasi wisata yang sudah mereka kenal.

Faktor penarik lainnya dalam kunjungan wisata adalah daya tarik kegiatan atau acara. Sejumlah perjalanan berpusat pada berbagai acara termasuk konser, olahraga, pameran dan pesta. Banyak orang mengaku bahwa mereka tidak akan berada di tempat tertentu (pada waktu itu) jika bukan karena acara tersebut. Motif ini sangat spesifik dalam keputusan perjalanan, karenanya lebih cenderung dimaknai sebagai faktor motivasi situasional yang hadir selama keputusan. (Decrop, A. and Snelders, D. 2004)

Variabel situasional sangat berpengaruh dalam proses pengambilan keputusan, misalnya saja keputusan yang mendadak, terutama yang berasal dari setiap aspek kehidupan seseorang. Secara keseluruhan, pengambilan keputusan perjalanan atau liburan itu bersifat multimotivation dan berubah sesuai dengan sifat 
liburan yang akan diambil.(Chang, L., Stylos, N., Yeh, S. and Tung, Y. 2015)

\section{B. PROSES KEPUTUSAN WISATAWAN}

Proses pengambilan keputusan wisatawan berlangsung dalam tahapan yaitu pengenalan kebutuhan, pra-pembelian, pilihan dan pembelian dan evaluasi pasca pembelian.

1. Pengenalan Kebutuhan

Ini merupakan titik awal dari kebanyakan model yang diawali dengan berbagai pengamatan berikut. Pertama, kebutuhan untuk melakukan perjalanan sering berasal dari faktor situasional tertentu dalam kehidupan masyarakat dalam merangsang kebutuhan awal melakukan perjalanan. Faktor-faktor situasional jarang diakui dalam model tradisional. Kedua, keinginan untuk melakukan perjalanan mengalami perubahan signifikan dalam memenuhi kebutuhan berwisata. Ketiga, keputusan generik - apakah atau tidak melakukan perjalanan adalah penting dalam banyak keputusan liburan.
Keputusan generik sering sebagai sebuah ritual tahunan tanpa banyak kendala. Oleh karena itu, keputusan generik untuk berlibur sering menjadi aspek penting dari proses pengambilan keputusan. Keputusan generik tidak selalu mengikuti runtutan rasional dalam pengambilan keputusan.(Bloy, D. 2000) Misalnya, orang kadang memiliki ide untuk melakukan perjalanan, memeriksa alternatif, pilih salah satu yang mereka inginkan, tapi mungkin tidak membuat keputusan untuk melakukan perjalanan.

2. Pre-Purchase Behavior

Perilaku pra-pembelian merupakan tahap kedua dalam pengambilan keputusan berwisata, setelah motif yang merangsang keinginan untuk melakukan perjalanan, pencarian informasi dan tingkat keterlibatan. Dalam hal "push and pull" faktor yang menonjol dalam keputusan city tour dibandingkan dengan motif liburan menunjukkan perbedaan yang menarik seperti dalam tabel 2 di mana push and pull factors sebagai alasan untuk melakukan perjalanan.(Al-Kwifi, Osama Sam. 2015)

\section{Tabel 2. Push and Pull factors}

\begin{tabular}{|l|r|l|r|}
\hline \multicolumn{2}{|l|}{ Push factors } & \multicolumn{2}{|}{ Pull factors } \\
\hline City Tour & Liburan & City Tour & Liburan \\
\hline Escape & Relax & Convenience access & Positive/fun image \\
\hline Socialize (internal) & Social & Cost of tour & Quality of facilities \\
\hline $\begin{array}{l}\text { Self esteem (gift } \\
\text { giving) }\end{array}$ & Escape & $\begin{array}{l}\text { Fun destination } \\
\text { image }\end{array}$ & Cost of trip \\
\hline Excitement & Excitement & Pre arranged event & Previous visit \\
\hline Socialize (external) & Prestige & Friendly image & Visiting friends \& relatives \\
\hline Relax & Education & Previous visit & \\
\hline & & Tourist sites & \\
\hline
\end{tabular}


Dalam model perilaku wisata sedikit tidak biasa bahwa pencarian informasi, evaluasi alternatif, dan pembelian dikelompokkan bersama. Dalam kasus city tour orang terlibat dalam tiga kegiatan itu scara bersama-sama dengan cara serampangan. Dalam beberapa kasus, evaluasi alternatif dilewati dan orang langsung ke tahap pembelian. Dalam situasi lain, orang mencari informasi dan mengevaluasi alternatif secara bersamaan sebelum membeli. Tidak diragukan lagi, kehadiran Internet adalah salah satu alasan utama dalam pola pengambilan keputusan. Orang bisa mencari informasi penawaran, mengevaluasi, dan membuat pemesanan, hanya dengan beberapa klik mouse.

Pra-keputusan merupakan aliran proses kritis dari rangsangan untuk membuat keputusan mencakup: preferensi, keputusan, dan pembelian. Proses preferensi mencakup: proses filterisasi stimulus, perhatian, pembelajaran, dan kriteria pilihan. Keputusan ini menghasilkan kecenderungan psikologis dalam hal niat ke arah tindakan pembelian. Preferensi dan keputusan mengarah pada tindakan membeli paket untuk tujuan liburan.(Law, Rob. Buhalis, Dimitrios and Cobanoglu, Cihan. 2014)

\section{a. Pencarian Informasi}

Dalam pariwisata, pencarian informasi yang paling umum dilakukan orang adalah. Pertama, untuk memperoleh berbagai informasi yang orang berkonsultasi dengan orang lain sebelum membeli (termasuk memori kunjungan sebelumnya) baik untuk liburan domistik maupun internasional. Kedua, pola pencarian informasi dilakukan secara langsung melalui Internet, keluarga dan teman-teman. Internet banyak digunakan oleh wisatawan terutama dalam situasi di mana pengambilan keputusan jangka waktu yang pendek (mungkin karena tidak punya waktu untuk mengumpulkan brosur dan materi-materi promosi lainnya).(Dunne, Gerard; Flanagan, Sheila; and Buckley, Joan. 2011

Internet memainkan peran penting dan menjadi kecenderungan umum terhadap perilaku pencarian informasi menit terakhir dalam model pengambilan keputusan kontemporer. Ruang lingkup dan skala informasi saat ini tersedia secara online, dan dalam banyak kasus, internet menjadi one-stop shop dalam pencarian informasi, menghilangkan kebutuhan untuk berkonsultasi (untuk mencari informasi).

Dalam banyak hal internet memotong model keputusan multistage, dan mencerminkan realitas modern ketika orang memutuskan untuk melakukan perjalanan dalam situasi di mana mereka semakin keterbatasan waktu, perhatian, dan pengolahan ragam informasi. Internet merupakan media modern dan ke depan internet akan menjadi sumber informasi yang paling dominan dalam sepanjang proses pengambilan keputusan.

\section{b. Tingkat Keterlibatan}

Tingkat keterlibatan terkait dengan jumlah waktu dan upaya dalam keputusan pembelian paket perjalanan. Literatur menunjukkan produk layanan memiliki risiko fungsional, keuangan, fisik, psikologis, dan sosial tertentu bagi wisatawan. Keinginan untuk mengurangi risiko menyebab-kan orang untuk terlibat dalam banyak perencanaan pra-pembelian dan upaya pencarian informasi. (Cai, Liping A, Feng, Ruomei and Breiter, Deborah 2004

Sebagian besar risiko merupakan hasil dari keterlibatan perilaku pencarian rendah terutama yang berkaitan dengan ukuran dan biaya perjalanan. Takut risiko ekonomi sering menyebabkan investasi 
waktu, tenaga dan sumber daya dalam pengambilan keputusan menjadi tinggi.( Moore, Kelvyn. Berger, Paul D. and Weinberg, Bruce D.2013) Berwisata dalam waktu yang lebih pendek dan lebih murah dianggap kurang berisiko dibandingkan dengan liburan panjang yang memerlukan lebih banyak waktu dalam perencanaan.

Keterlibatan perilaku rendah dalam situasi liburan kunjungan ulang/revisit, atau loyalitas destinasi. Secara umum, faktorfaktor seperti pesta, jenis destinasi, durasi, dan organisasi perjalanan (paket atau independen) cenderung memiliki pengaruh kuat pada tingkat keterlibatan rendah dalam semua keputusan liburan pada wisatawan psychocentric untuk. mengurangi ketidaknyamanan dan mengurangi resiko.

Secara teoritis tingkat keterlibatan wisatawan memiliki dampak terhadap kepuasan, sementara kepuasan mempengaruhi pilihan produk dan tingkat kepuasan yang tinggi mengarah ke tingkat keterlibatan yang lebih tinggi yang pada umumnya merupakan karakteristik wisatawan allocentric yang cenderung mencari destinasi baru, selalu ingin tahu, suka petualangan dan menyukai perjalananperjalanan penuh tantangan.(Kastenholz, Elisabeth. Eusebio, Celeste and Carneiro, Maria Joao. 2013)

\section{c. Evaluasi Alternatif}

Utilitas alternatif akan sering bergantung pada situasi. Sebagai contoh, beberapa produk hanya memiliki nilai musiman (misalnya, kartu ucapan), ada pula yang terkait dengan sekali dalam peristiwa kehidupan (misalnya, gaun pengantin), dan beberapa hanya digunakan dalam keadaan darurat (misalnya, layanan rumah sakit).

Dalam konsep dinamika stimulus mengakui pentingnya pembelajaran yang terjadi sebagai hasil dari pengalaman dengan situasi pekerjaan tertentu sebelumnya dengan mendefinisikan konstruksi inhibitor sebagai kekuatan noninternal yang menghambat preferensi pembeli. Konsep inhibitor yang lebih formal dikembangkan dalam model hubungan sikap-perilaku sebagai situasi yang diantisipasi dan kejadian tak terduga. Menyadari perilaku yang tidak dapat secara akurat dapat diprediksi berdasarkan sikap atau niat yang berkaitan dengan faktor situasional.

Salah satu faktor yang paling menarik dari sejumlah kecil alternatif yang dipertimbangkan oleh sebagian besar wisatawan adalah tanpa mempertimbangkan alternatif lain. Ini sangat dimungkinkan jika wisatawan yang terlibat dalam peluang kegiatan tertentu yang menarik, olahraga, konser, dan lainnya.

Skenario seperti itu umumnya tidak melibatkan alternatif lain dan jika acara tidak terjadi di tempat yang mereka kunjungi, wisatawan akan mempertimbangkan alternatif lain. Evaluasi ini dapat menjadi indicator keberhasilan penyedia layanan pariwisata terutama ketika wisatawan berkomentar : saya/kami tidak melihat di tempat lain, kami datang terutama untuk permainan, jika ini tidak ada, saya/kami tidak akan berada di sini sekarang.

3. Pilihan dan Pembelian

Nilai Sebagai Driver Keputusan Pembelian

Setiap keputusan dipengaruhi oleh keadaan pribadi (mis masalah uang, komitmen pekerjaan, tanggung jawab rumah tangga) serta nilai-nilai konsumsi akan mempengaruhi perilaku pilihan dan pembelian wisatawan, yaitu nila fungsional, sosial, kondisional, emosional, dan nilainilai epistemik. Setiap atau semua nilainilai konsumsi dapat mempengaruhi keputusan.(Denys, Vasyl and Mendes, 
Júlio. 2012) Berbagai disiplin ilmu seperti ekonomi, sosiologi, psikologi, pemasaran dan perilaku konsumen memberi kontribusi teoritis dalam membentuk model (Bieger, J.R. and Laesser, C. 2004. Information sources for travel decisions: towards a source process model)

a. Nilai Fungsional

Nilai fungsional didefinisikan sebagai: utilitas yang dirasakan diperoleh dari alternatif kinerja fungsional, utilitarian, atau fisik. Sebuah alternatif memperoleh nilai fungsional melalui kepemilikan atribut fungsional, utilitarian, atau fisik yang menonjol. Nilai fungsional diukur dari profil pilihan atribut.

Nilai fungsional diduga menjadi pendorong utama dalam pilihan wisatawan. Asumsi ini mendasari teori utilitas ekonomi dinyatakan dalam "rational economic man". Nilai fungsional mungkin berasal dari karakteristik atau atribut, seperti keandalan, daya tahan, dan harga. Misalnya, keputusan untuk membeli mobil tertentu mungkin didasarkan pada nilai ekonomis bahan bakar dan pemeliharaan.

Dengan mengidentifikasi fungsi dominan produk (yaitu, manfaat utama), marketer bisa menekankan manfaat dalam komunikasi dan kemasan mereka. Iklan yang relevan dengan fungsi meminta pikiran yang lebih baik tentang apa yang sedang dipasarkan dan dapat menghasilkan preferensi tinggi untuk iklan dan produk, Teori fungsional sikap mengidentifikasi empat sikap didasarkan pada nilai-nilai fungsional:

- Fungsi utilitarian, fungsi terkait dengan prinsip-prinsip dasar reward and punishment. Sikap terhadap produk berdasarkan pada apakah produk wisata ini memberikan kesenangan / menyenangkan atau mengecewakan.

- Fungsi ekspresif, fungsi nilaiekspresif mengungkapkan nilainilai atau diri sentral konsep diri wisatawan. Seseorang membentuk sikap terhadap produk bukan karena manfaat destinasi wisatanya, tetapi karena apa yang dikatakan produk tentang dia sebagai pribadi.

- Fungsi ego-defensif. Sikap dibentuk untuk melindungi orang, baik dari ancaman eksternal atau perasaan internal melakukan fungsi ego-defensif. Contoh fungsi ini adalah kampanye deodoran yang menekankan pada tidak menyenangkan, dan memalukan karena bau ketiak di depan umum.

- Fungsi pengetahuan, sikap ini terbentuk sebagai hasil dari kebutuhan untuk pesanan, struktur, atau makna. Kebutuhan ini sering hadir ketika seseorang dalam situasi ambigu atau dihadapkan dengan produk baru.

b. Nilai Sosial

Nilai sosial didefinisikan sebagai persepsi utilitas yang diperoleh dari alternatif hubungan dengan satu atau lebih kelompok sosial. Alternatif memperoleh nilai sosial melalui hubungan dengan kelompokkelompok demografis, sosial ekonomi, dan budaya, etnis positif atau negatif. Stereotipe nilai sosial diukur dari pilihan profil citra.

Citra sosial mengacu pada semua kelompok referensi primer dan 
sekunder yang relevan cenderung mendukung konsumsi produk. Wisatawan memperoleh stereotipe positif atau negatif berdasarkan hubungan mereka dengan beragam demografi (usia, jenis kelamin, agama), sosial ekonomi (pendapatan, pekerjaan), budaya, etnis (ras, gaya hidup), atau politik, dan ideologi masyarakat.

Pilihan terhadap barang (misalnya, pakaian, perhiasan) untuk berbagi dengan orang lain (misalnya, hadiah, produk yang digunakan dalam menghibur) sering didorong oleh nilai-nilai sosial. Misalnya, mobil yang sedang dipilih untuk citra sosial dari kinerja fungsional..

c. Nilai Emosional

Nilai emosional didefinisikan sebagai: persepsi utilitas yang membangkitkan perasaan tertentu Emosi merujuk pada serangkaian respon emosional selama penggunaan produk atau pengalaman konsumsi, serta ekspresi pengalaman emosional (misalnya, sukacita, kemarahan, dan rasa takut) atau dengan dimensi struktural yang mendasari kategori emosional seperti kenikmatan/ ketidaknyamanan, relaksasi/ tindakan, atau ketenangan/ kegembiraan. Barang dan jasa sering dikaitkan dengan respons emosional (misalnya rasa takut terangsang saat melihat film horor).

Nilai emosional juga sering dikaitkan dengan estetika. Produk yang memiliki nilai-nilai emosional dalam makanan yang membangkitkan perasaan nyaman melalui hubungan dengan pengalaman masa kecil. Nilai emosional dapat diukur dari minat, sukacita, kejutan, kesedihan, kemarahan, jijik, penghinaan, ketakutan, malu, dan rasa bersalah.

d. Nilai Epistemik

Nilai epistemik didefinisikan sebagai: Persepsi utilitas yang membangkitkan rasa ingin tahu, memberikan kebaruan, dan atau memenuhi keinginan untuk memperoleh nilai pengetahuan Nilai epistemik mengacu pada rasa ingin tahu, kebaruan, dan pengetahuan"

Isu epistemik menjadi alasan yang membenarkan kepuasan yang dirasakan dari rasa ingin tahu, pengetahuan, dan kebutuhan eksplorasi yang ditawarkan oleh produk sebagai kecepatan perubahan (sesuatu yang baru, yang berbeda). Setiap pengalaman baru tentu memberikan nilai epistemik.

Dalam bisnis kuliner alternatif dapat dipilih karena wisatawan bosan atau kenyang dengan produk makanan saat ini (dan mencoba jenis makanan baru), penasaran (seperti dalam mengunjungi kompleks perbelanjaan baru), atau memiliki keinginan untuk belajar (seperti dalam mempelajari atau mengalami budaya lain). Bagi wisatawan allocentric, eksplorasi hal-hal baru, ragam motif pencarian produk, percobaan, dan peralihan perilaku (switching behavior) menjadi kontributor paling signifikan untuk mengadopsi produk baru.

e. Nilai Bersyarat

Nilai bersyarat (conditional value) didefinisikan sebagai persepsi utilitas yang diakuisisi dari hasil pilihan situasi tertentu yang meningkatkan nilai fungsional atau nilai sosial Nilai bersyarat diukur dariprofil kontinjensi pilihan. 
Teori lima nilai ini menjadi kontributor diferensial dalam konteks pilihan spesifik. Misalnya, konsumen dapat memutuskan untuk membeli koin sebagai upaya melindungi nilai inflasi (nilai fungsional), dan juga mewujudkan rasa aman (nilai emosional) dari investasi. Nilai sosial, epistemik, dan nilai kondisional memiliki sedikit pengaruh.

Keputusan untuk membeli mungkin secara positif dipengaruhi oleh lima nilai ini. Misalnya, untuk pembeli rumah pertama kali, pembelian rumah mungkin memberikan nilai fungsional (rumah mengandung lebih banyak ruang daripada apartemen), nilai-nilai sosial (teman juga membeli rumah), nilainilai emosional (konsumen merasa aman karena telah memiliki rumah), nilai epistemik (kebaruan membeli rumah adalah menyenangkan), dan nilai bersyarat (memulai sebuah keluarga).

Daerah Tujuan Wisata Sebagai Driver Pembelian

Proses pilihan daerah tujuan wisata (tourists destination choice process) dalam konsep permintaan pariwisata berkaitan dengan dua hal pokok (1) memprediksi jumlah wisatawan yang diharapkan tiba di daerah tujuan wisata (DTW) tertentu, dan (2) memahami pilihan DTW berdasarkan variabel geografi, demografi, psikografi, dan perilaku.

Sebelum memutuskan kemana pergi berlibur, sebagian besar wisatawan membuat beberapa keputusan, sebagian lainnya keputusan direncanakan secara sempurna, lainnya mungkin mengimpr`ovisasi perencanaan, dan beberapa lainnya membuat semua keputusan secara bersa-maan atau dalam berbagai tahap. Apakah direncanakan atau tidak, sadar atau tidak sadar, proses keputusan perjalanan liburan tergantung pada keputusan waktu; keputusan anggaran; frekuensi dan keputusan lama tinggal; keputusan jenis destinasi; dan pilihan destinasi dan transportasi.(Eugenio-Martin, Juan L. 2003)

\section{a. Keputusan Waktu}

Keputusan tentang waktu (timing decision) menunjuk pada pilihan apakah atau tidak bepergian dalam jangka waktu tertentu - pengaturan interval waktu - periode tahunan. Periode kunjungan liburan di Indonesia seperti divisualisasikan dalam tabel 1.

\section{b. Konstrain Anggaran Pariwisata}

Setelah individu atau komunitas atau keluarga telah memutuskan untuk melakukan perjalanan, mereka harus memutuskan, baik secara sadar atau tidak sadar, berapa banyak pengeluaran pariwisata (tourism budget constraint). Keputusan ini tergantung pada pendapatan dan preferensi individu. Anggaran berwisata dapat diperkirakan sebagai persentase dari pen-dapatan, yaitu rasio antara pengeluaran pariwisata dan pendapatan. formulasi baru ini me-mungkinkan perkiraan berapa banyak orang memilih untuk mendistribusikan pendapatan mereka untuk tujuan wisata. Efek marginal keputusan ini mengungkapkan perbedaan enjoyability wisatawan sehubungan dengan kemungkinan perubahan di salah satu variabel sosio-ekonomi mereka. 


\section{c. Frekuensi dan Lama Tinggal}

Frekuensi berkaitan dengan seberapa sering melakukan perjalanan, sementara lama tinggal berkaitan dengan jumlah hari yang digunakan untuk tinggal di destinasi. Kendala anggaran, memaksa individu untuk memutuskan seberapa sering melakukan perjalanan dan berapa lama tinggal (frequency and length of stay) di destinasi. Kedua keputusan saling tergantung satu sama lain karena tinggal lebih lama dapat mempengaruhi frekuensi perjalanan dan sebaliknya.

\section{d. Jenis Destinasi}

Keputusan ini berkaitan dengan kemana harus melakukan perjalanan yang berbeda (kind of destination). Saat ini, pilihan perjalanan cukup besar dan destinasi wisata sangat bervariasi. Masing-masing memiliki fitur dan karakteristik khusus yang membuat mereka unik. Beberapa destinasi dapat memenuhi hampir setiap jenis kebutuhan umum wisatawan, tapi mungkin tidak memenuhi kebutuhan sebagian kecil wisatawan. Heterogenitas kebutuhan menciptakan deferensiasi keinginan terhadap destinasi yang ideal dalam memuaskan kebutuhan mereka.

Dalam tahap ini wisatawan membuat dua keputusan secara simultan. Pertama, keputusan menyangkut sifat perjalanan, wisatawan harus menentukan jenis destinasi wisata yang diinginkan; misalnya, akrab, petualang atau perjalanan santai. Kedua, keputusan menyangkut pilihan untuk mengunjungi atribut fisik, misalnya mengunjungi gunung tertentu, kota, resort pedesaan,resort pantai atau lainnya.

\section{e. Pilihan Destnasi dan ModaTransportasi}

Keputusan ini terkait dengan pilihan moda transportasi (destination and transportation mode choice). Untuk kepentingan wisatawan dengan jarak yang jauh atau karena kendala tertentu, pesawat adalah pilihan moda transportasinya. Untuk perjalanan jarak pendek mungkin moda transportasi pilihanya adalah kereta api atau bus pariwisata dan lainya yang paling sesuai.

4. Evaluasi Pasca Pembelian

Evaluasi pasca pembelian ini merupakan evaluasi dari setiap titik sentuh layanan pariwisata, sejak wisatawan membuat komitmen pembelian, selama parjalanan, kegiatan di destinasi, dan destinasi itu sendiri, wisatawan akan memberi penilaian pada penyedia layanan wisata.

Proses evaluasi pasca pembelian, di mana pengunjung mengukur pengalaman produk terhadap ekspektasi pra-konsumsi. Hasil dari proses ini umumnya dinyatakan dalam hal kepuasan atau ketidakpuasan dan biasanya memiliki pengaruh pada perilaku pembelian masa depan.

Daya tarik wisata, keramahan dan menyenangkan adalah tema umum yang sering digunakan dalam menilai perjalanan wisatawan secara keseluruhan. Penilaian wisatawan dapat menghasilkan komentar negatif paling umum terkait dengan harga tinggi, sampah, kemacetan dan hosting yang tertutup, tidak ramah, dan tidak menyenangkan, dan sebaliknya menjadi komentar positif.

Evaluasi pasca pembelian memiliki dampak yang signifikan pada pembuat keputusan, sikap dan atau perilaku 
berikutnya. Bagi pengusaha pariwisata, evaluasi pasca pembelian berfungsi sebagai umpan balik untuk tiga tujuan. Pertama, mempersiapkan tambahan pengalaman bagi wisatawan. Kedua, memberi kesempatan mengevaluasi keputusan yang berhubungan dengan pasar. Ketiga, mennyediakan dasar untuk melayani dan menyesuaikan perilaku pembelian masa depan.

Salah satu elemen kunci yang mempengaruhi harapan traveler adalah kepuasan. Kepuasan akan mempengaruhi pengambilan keputusan perjalanan atau kegiatan rekreasi di masa depan, mendorong kemungkinan kunjungan ulang atau pembelian ulang produk atau layanan wisata. Prospek pembelian ulang terjadi dalam dua kemungkinan : (a) membeli kembali dalam waktu yang berbeda, dan (b) pembelian ulang berubah berdasarkan perubahan produk wisata baru atau kualitas layanan yang lebih baik.

\section{OUTPUT}

Efek penting dari pengalaman positif adalah kepuasan, kunjungan ulang dan pembelian produk wisata secara berulang (Eugenio-Martin, Juan L. 2003)

\section{Kepuasan}

Para akademisi marketing berupaya menjelaskan hubungan kasual kepuasan dengan niat revisit, niat pembelian ulang, dan promosi mulut ke mulut untuk berbagai destinasi wisata.. Kepuasan terhadap pengalaman masa lalu memiliki hubungan positif dengan kepuasan terhadap kunjungan saat ini untuk destinasi yang sama, dan kepuasan dalam kunjungan saat ini, pada gilirannya, mempengaruhi niat kembali di masa depan dan rekomendasi dari pengalaman orang lain. Kepuasan mempengaruhi perilaku revisit dalam tiga cara: niat untuk mengulang kunjungan liburan di destinasi yang sama dalam jangka waktu yang nyata (yaitu, tahun depan atau perjalanan ke luar negeri berikutnya), niat untuk merekomendasikan, dan niat untuk menggunakan liburan serupa di destinasi lain di negara yang sama. ${ }^{32}$

Perilaku masa depan belum tentu berasal dari kepuasan terutama wisatawan allocentric, wisatawan mungkin akan terpengaruh oleh faktor-faktor lain, seperti filosofi wisata, ciri-ciri kepribadian, dan pengalaman sebelumnya. Mainstream harapan, persepsi performance, pengalaman masa lalu dan standar normatif tentang produk wisata memiliki dampak langsung pada niat kunjungan dari tahun ke tahun di masa depan akan memilih destinasi yang berbeda atau beralih secara terus menerus dan repeater terus menerus sebagai karateristik wisatawan psychocentric.

\section{Niat Kunjungan Ulang}

Niat didefinisikan sebagai kecenderungan konsumen untuk membeli produk atau merek selama periode waktu tertentu. Niat dipahami sebagai keadaan kognitif yang mencerminkan rencana konsumen untuk membeli unit produk atau merek tertentu dalam beberapa periode waktu tertentu. Niat merefleksikan sikap, keyakinan, dan antisipasi konsumen terhadap kendala tertentu yang menghambat rencana pembelian konsumen.

Para akademisi marketing, niat digunakan sebagai ukuran yang mewakili perilaku pembelian dari internal konsumen dalam menanggapi suatu produk akan menyebabkan pembelian produk aktual. Perilaku berkaitan dengan niat perilaku daripada sikap, keyakinan, atau perasaan. Dengan demikian niat perilaku menghasilkan prediksi yang paling akurat pada perilaku masa depan. Selain itu niat juga dapat digunakan sebagai prediktor perilaku pembelian produk yang sudah ada daripada untuk produk baru. 
Niat kunjungan ulang (revisit) sebagai konstruk penting dalam pemasaran destinasi wisata untuk memprediksi perilaku masa depan wisatawan. Niat revisit melibatkan power kognitif dalam rencana wisatawan untuk kembali ke destinasi wisata selama periode waktu tertentu.

Kunjungan ke destinasi untuk pertama kali yang menghasilkan kepuasan akan menjadi driver niat kunjungan ulang. Niat kunjungan ulang merupakan probabilitas pembelian berulang, menjadi anteseden perilaku perjalanan berikutnya ke destinasi yang sama atau menggunakan penyedia layanan wisata yang sama.

Niat revisit adalah salah satu dari empat dimensi evaluasi terkait dengan reaksi ke destinasi. Niat revisit merupakan dimensi penting dalam mengukur loyalitas perilaku. Berdasarkan serangkaian pembelian sebelumnya, probabilitas pembelian ulang pada dasarnya memproyeksikan perilaku pembelian masa depan.

\section{Niat Pembelian Ulang Produk Wisata}

Perkiraan akurat terhadap perilaku wisatawan 'sangat penting dalam memastikan pengembangan produk yang sukses dan pengambilan keputusan. Niat pembelian ulang dapat menjadi alat yang bermanfaat bagi marketer destinasi untuk membuat keputusan strategis tentang produk wisata yang ada dan program promosi yang proporsional. Pengetahuan tentang permintaan di masa mendatang diperlukan untuk menentukan apakah ada permintaan yang cukup di pasar, menjamin introduksi produk baru di destinasi, segmen perjalanan wisata harus ditargetkan, dan apakah perubahan harga harus dilakukan untuk memenuhi fluktuasi permintaan pasar.

\section{KESIMPULAN}

Artikel ini menunjukkan pentingnya jenis perjalanan sebagai penentu perilaku pengambilan keputusan di mana pilihan konteks dibuat. Model perilaku konsumen dalam produk barang tidak sepenuhnya dapat digunakan dalam bisnis produk wisata kontemporer seperti kebutuhan istirahat di sebuah destinasi.

Dalam model perilaku pengambilan keputusan berwisata, di mana nilai fungsional, nilai social, nilai emosional, nilai epistemik dan pilihan daerah tujuan wisata memiliki daya dorong yang berbeda bagi karakter wisatawan psychocentric dan wisatawan allocentric dalam melakukan jenis perjalanan.

Keputusan berwisata ke destinasi ditandai dengan keterlibatan perilaku baik rendah maupun tinggi memiliki efek tehadap kepuasan wisatawan. Efek perjalanan positif akan menghasilkan kepuasan, niat pembelian ulang dan niat pembelian ulang produk wisata. Pemahaman karakteristik keputusan perjalanan tertentu seperti untuk kebutuhan istirahat atau lainnya memberikan kontribusi yang sangat bermanfaat bagi marketer dalam rancang bangun program dan strategi pemasaran pariwisata

\section{DAFTAR PUSTAKA}

Abraham Pizam and Yoel Mansfeld. 2009. Consumer Behavior in Travel and Tourism. New York: Routledge

Al-Kwifi, Osama Sam. 2015. The impact of destination images on tourists' decision making: A technological exploratory study using functional technological-oriented magnetic resonance imaging. Journal of Hospitality and Tourism Technology. Vol 6. No 2: 174-194. 
Anshul Garg. 2015. Travel Risks vs Tourist Decision Making: A Tourist Perspective. International Journal of Hospitality \& Tourism Systems. Vol 8 No 1: 1-9

Aris Riyanta, 2016. Laporan Kinerja Dinas Pariwisata DIY. Yogyakarta: Dinas Pariwisata Daerah Istimewa Yogyakarta.

Bieger, J.R. and Laesser, C. 2004. Information sources for travel decisions: towards a source process model. Journal of Travel Research, Vol. 42 No. 4: 234-48.

Bloy, D. 2000. An assessment of berwisataist motivations within a multiple holiday taking context. Business Education Publishers, Sunderland : 27-44.

Cai, Liping A, Feng, Ruomei and Breiter, Deborah 2004. Tourist purchase decision involvement and information preferences. Journal of Vacation Marketing. Vol 10. No 2 : 138-148.

Chang, L., Stylos, N., Yeh, S. and Tung, Y. 2015. How do Motivation, Pre-Visit Information Search and Destination Image affect Post-Visit Behavioural Intention of an destination. Journal of Tourism Research. 9: 8-23

Decrop, A. 2007. The formation of destination choice sets: new light through old windows. paper presented at 2007 Advances in Tourism Marketing Conference, 10-12 September, Valencia.

Decrop, A. and Snelders, D. 2004. Planning the summer vacation: an adaptable process. Annals of Tourism Research, Vol. 31 No. 4: 10081030

Denys, Vasyl and Mendes, Júlio. 2012. Consumption Values and destination evaluation in destination decision making. Journal of Spatial and Organizational Dynamics, Vol.2, Issue 1: 4-22

Drew, Martin and Woodside, Arch G. 2012. Structure and process modeling of seemingly unstructured leisure-travel decisions and behavior. International Journal of Contemporary Hospitality Management. Vol 24.No 6: 855872.

Dunne, Gerard; Flanagan, Sheila; and Buckley, Joan. 2011. Towards a decision making model for travel. International Journal of Culture, Tourism and Hospitality Research. Vol 5. No 2: 158-172.

Eugenio-Martin, Juan L. 2003. Modelling determinants of tourism demand as a five-stage process: Tourism and Hospitality Research. Vol 4. No. 4: 341-354.

Gnanapala. W. K. A. 2015. Tourists Perception and Satisfaction: Implications for Destination Management. Journal of Marketing Research. Vol. 1, No. 1: 7-19

Hyde, Kenneth F, and; Decrop, Alain. 2011. New perspectives on vacation decision making. International Journal of Culture, Tourism and Hospitality Research. Vol 5. No 2: 103-111.

Jeng, J. and Fesenmaier, D.R. 2002. Conceptualizing the travel decisionmaking hierarchy: a review of recent developments. Tourism Analysis, Vol. 7: 15-32.

Kastenholz, Elisabeth. Eusebio, Celeste and Carneiro, Maria Joao. 2013. Studying factors influencing repeat visitation of cultural tourists. 
Journal of Vacation Marketing. 10/19: 343-358,

Katsoni, Vicky

and

Venetsanopoulou.Maria. 2013. Use

of innovation systems for an effective tourism marketing development strategy. e-Journal of Science \& Technology. Vol 5 No 8: 33-40

Law, Rob. Buhalis, Dimitrios and Cobanoglu, Cihan. 2014. Progress on information and communication technologies in hospitality and tourism. International Journal of Contemporary Hospitality Management. Vol. 26 No. 5: 727750

Luo, S J; Hsieh, L Y. 2013. Reconstructing Revisit Intention Scale in Tourism. Journal of Applied Sciences. 13.18: 3638-3648.

Martin, D. and Woodside, A.G. 2011, "Gestalt modeling of international tourism behavior: advancing grounded theory ", Psychology \& Marketing, Vol. 28 No. 10: 9981026.

Minciu, Rodica and Moisă, Claudia, Olimpia. 2009. Fundamental Aspects Regarding Youth and Their Decision to Practice Tourism. Annal Series of Economica, Vol 11 No 2: 1009 - 1018

Moore, Kelvyn. Berger, Paul D. and Weinberg, Bruce D.2013. Issues for Exploration of Differing Values among Sub-groups of Young-Adult Consumers. International Journal of Business and Social Science. Vol. 4 No. 5: 35-39

Moore, Kevin. Smallman, Clive. Wilson, Jude and Simmons, David. 2012. Dynamic in-destination decisionmaking: An adjustment model.
Tourism Management. Vol 33 Issue 3: 635-645

Richter, L.K. 2003, 'International tourism and its global public health consequences. Journal of Travel Research, Vol. 41 No. 4: 340-347.

Sava, Cipriana,2013. The Evolution of Regional Accommodation Capacity Development Region. Knowledge Horizons. Economics Vol 5.No 2 : $82-86$

Sharma, A. and Christie, I.T. 2010. Performance assessment using value-chain analysis. International Journal of Contemporary Hospitality Management, Vol. 22 No. 3: 282-99.

Sirakaya, E. and Woodside, A.G. 2005, Building and testing theories of decision making by travelers. Tourism Management, Vol. 26 No. 6: 815-32.

Sung, H.H., Morrison, A.M., Hong, G.S. and O'Leary, J.T. 2001. The effects of household and trip characteristics on trip types: a consumer behavioural approach for segmenting the domestic leisure travel market. Journal of Hospitality \& Tourism Research, Vol. 25 No. 1: 46-68.

Swarbrooke, J. and Horner, S. 2007, Consumer Behavior in Tourism, 2nd ed. Butterworth-Heinemann, Oxford.

Trew, J. and Cockerell, N. 2002. The market for city breaks. Insights, Vol. 14 No. 58: 85-111. 